$1-2013$

\title{
Planning Prompts as a Means of Increasing Preventive Screening Rates
}

Katherine L. Milkman

University of Pennsylvania

John Beshears

James J. Choi

David Laibson

Brigitte C Madrian

Follow this and additional works at: https://repository.upenn.edu/fnce_papers

Part of the Finance and Financial Management Commons, and the Medicine and Health Sciences Commons

\section{Recommended Citation}

Milkman, K. L., Beshears, J., Choi, J. J., Laibson, D., \& Madrian, B. (2013). Planning Prompts as a Means of Increasing Preventive Screening Rates. Preventive Medicine, 56 (1), 92-93. http://dx.doi.org/10.1016/ j.ypmed.2012.10.021

This paper is posted at ScholarlyCommons. https://repository.upenn.edu/fnce_papers/85

For more information, please contact repository@pobox.upenn.edu. 


\title{
Planning Prompts as a Means of Increasing Preventive Screening Rates
}

\author{
Abstract \\ In the U.S., 18,800 lives could be saved annually if those advised to obtain colorectal screenings based on \\ national guidelines complied (Zauber et al., 2012). Subtle suggestions embedded in a decision-making \\ environment can change people's choices (Thaler and Sunstein, 2008). Past research has shown that \\ prompting people to form plans about where and when they will complete an intended behavior increases \\ engagement in activities ranging from voting to vaccination (Gollwitzer and Sheeran, 2006; Milkman et al., \\ 2011; Nickerson and Rogers, 2010). When plans are formed, they link intended behaviors with a concrete \\ future moment and course of action, creating cues that reduce forgetfulness and procrastination. We \\ studied whether planning prompts increase colonoscopy rates. \\ Keywords \\ reminder systems, communication, economics, behavioral, primary prevention, colonoscopy, memory \\ Disciplines \\ Finance and Financial Management | Medicine and Health Sciences
}


Planning Prompts as a Means of Increasing Preventive Screening Rates

\author{
Katherine L. Milkman, Ph.D. \\ The Wharton School, University of Pennsylvania \\ kmilkman@wharton.upenn.edu \\ (corresponding author) \\ John Beshears, Ph.D. \\ Graduate School of Business, Stanford University \\ beshears@stanford.edu \\ James J. Choi, Ph.D. \\ School of Management, Yale University \\ james.choi@yale.edu \\ David Laibson, Ph.D. \\ Department of Economics, Harvard University \\ dlaibson@harvard.edu \\ Brigitte C. Madrian, Ph.D. \\ John F. Kennedy School of Government, Harvard University \\ brigitte_madrian@harvard.edu
}

Article: 400 words

MeSH-heading Keywords. Reminder Systems; Communication; Economics, Behavioral;

Primary Prevention; Colonoscopy; Memory 
In the U.S., 18,800 lives could be saved annually if those advised to obtain colorectal screenings based on national guidelines complied (Zauber et al., 2012). Subtle suggestions embedded in a decision-making environment can change people's choices (Thaler and Sunstein, 2008). Past research has shown that prompting people to form plans about where and when they will complete an intended behavior increases engagement in activities ranging from voting to vaccination (Gollwitzer and Sheeran, 2006; Nickerson and Rogers, 2010; Milkman et al., 2011). When plans are formed, they link intended behaviors with a concrete future moment and course of action, creating cues that reduce forgetfulness and procrastination. We studied whether planning prompts increase colonoscopy rates.

In summer 2010, 11,918 employees from four U.S. companies were selected for the study because they were due for a colonoscopy according to the Centers for Disease Control criteria (USPSTF, 2008). Evive Health, a healthcare communications provider, randomly assigned these employees to a control or planning group and sent each a mailing explaining that national guidelines recommended they receive a colonoscopy. Mailings provided contact information for a proctologist, listed the percentage of cost covered by insurance, and emphasized that sticky notes help people remember to accomplish important tasks (like getting a colonoscopy). A blank yellow sticky note was attached to the top of the control group mailing. For the planning group, the mailing was identical, except the sticky note contained a six-word planning prompt:

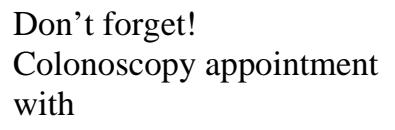

We analyzed colonoscopy medical claims of study participants from the time of the mailings through February 2011. The 7.2\% colonoscopy rate of the planning group was 
significantly higher than the $6.2 \%$ rate of the control group (Table 1), a relative increase of 15 percent.

If planning prompts reduce forgetfulness as hypothesized (Gollwitzer and Sheeran, 2006), they should help forgetful sub-populations most. Fifty-four MTurk respondents were asked which characteristics they believe are associated with forgetfulness. All of the identified characteristics (male, older, parent, lower insurance coverage, ignoring previous reminders) are associated with larger planning prompt treatment effects. A forgetfulness proxy, constructed by summing indicators for these five variables (calculated for age and coverage by dividing by their respective ranges), has a significant positive interaction with the treatment effect on colonoscopy receipt $(\mathrm{p}<0.05)$.

Our results show that planning prompts, at no additional cost and without restricting choice, can increase follow-through on unpleasant and temporally distant health behaviors like colonoscopies.

Conflict of Interest: The authors declare there is no conflict of interest. 


\section{ACKNOWLEDGEMENTS}

We thank Prashant Srivastava, Jennifer Lindner, and our other contacts at Evive Health for providing the study data. Michael Puempel provided excellent research assistance. We acknowledge individual and collective financial support from the National Institute on Aging (grants P01AG005842 and P30AG034532). See the authors' websites for lists of their outside activities. 


\section{REFERENCES}

Gollwitzer PM, Sheeran P, 2006. Implementation intentions and goal achievement: A metaanalysis of effects and processes. Adv Exp Soc Psychol 38:69-119.

Milkman KL, Beshears J, Choi JJ, Laibson D, Madrian BC, 2011. Using implementation intentions prompts to enhance influenza vaccination rates. PNAS 108:10415-10420.

Nickerson DW, Rogers T, 2010. Do you have a voting plan? Implementation intentions, voter turnout, and organic plan making. Psychol Sci 21:194-199.

U.S. Preventive Services Task Force, 2008. Screening for colorectal cancer: U.S. preventive services task force recommendation statement. External web site icon AHRQ publication 08-05124-EF-3, October 2008. Agency for healthcare research and quality, Rockville, MD.

Zauber AG, Winawer SJ., O'Brien MJ, Lansdorp-Vogelaar I, van Ballegooijen M, Hankey BF, Shi W, Bond JH, Schapiro M, Panish JF, Stewart ET, Waye JD, 2012. Colonoscopic polypectomy and long-term prevention of colorectal-cancer deaths. N Engl J Med. 366:687-696. 


\section{TABLE}

Table 1. Sample characteristics of U.S. employees at baseline and impact of summer 2010 Evive reminder mailing

\begin{tabular}{|c|c|c|c|}
\hline & $\begin{array}{c}\text { Full Sample } \\
(\mathrm{n}=11,918)\end{array}$ & $\begin{array}{c}\text { Control Group } \\
(\mathrm{n}=5,898)\end{array}$ & $\begin{array}{c}\text { Planning Group } \\
(n=6,020)\end{array}$ \\
\hline \multicolumn{4}{|l|}{ Baseline Sample Characteristics } \\
\hline Male (\%) & 50.77 & 50.32 & 51.21 \\
\hline Age & $57.5(4.9)$ & $57.5(4.8)$ & $57.5(4.9)$ \\
\hline Has 1+ Children (\%) & 9.85 & 9.63 & 10.07 \\
\hline Caucasian (\%) & 94.99 & 94.86 & 95.12 \\
\hline Black (\%) & 0.08 & 0.05 & 0.10 \\
\hline Hispanic (\%) & 4.68 & 4.83 & 4.53 \\
\hline Asian (\%) & 0.25 & 0.25 & 0.25 \\
\hline First Reminder (\%) & 76.80 & 77.08 & 76.53 \\
\hline Percent of Colonoscopy's Cost Covered by Insurance & $87.2(8.9)$ & $87.3(9.0)$ & $87.1(8.9)$ \\
\hline Employer 1 - Jun. Mailing (\%) & 15.47 & $16.1 \%^{\dagger}$ & 14.87 \\
\hline Employer 2 - Jul. Mailing (\%) & 1.33 & 1.44 & 1.21 \\
\hline Employer 3 - Aug. Mailing (\%) & 59.98 & 59.51 & 60.43 \\
\hline Employer 4 - Aug. Mailing (\%) & 23.23 & 22.96 & 23.49 \\
\hline \multicolumn{4}{|c|}{ Impact of Mailing: Outcome is Post-Mailing Colonoscopy Claims by Feb. 2011} \\
\hline Full Sample Colonoscopy Rate, Unadjusted (\%) & 6.69 & $6.21^{*}$ & 7.16 \\
\hline \multicolumn{4}{|l|}{ Difference Relative to the Control Condition } \\
\hline Unadjusted Difference (\%) & N/A & N/A & $0.95^{*}$ \\
\hline OLS Regression-adjusted Difference ${ }^{\mathrm{a}}(\%)$ & N/A & N/A & $0.95 *$ \\
\hline \multicolumn{4}{|c|}{$\begin{array}{l}+\mathrm{p}<0.10 ;{ }^{*} \mathrm{p}<0.05 \text {. Except in the case of regression-adjusted estimates, statistical significance reports rely on two sample t-test (for continuous } \\
\text { variables) and two sample proportions test (for dichotomous variables) comparing the control and treatment conditions. }\end{array}$} \\
\hline \multicolumn{4}{|c|}{$\begin{array}{l}\text { Ordinary least squares (OLS) regression controls include sex, age, parental status, race/ethnicity, whether a previous reminder was ignored, } \\
\text { colonoscopy percent coverage, and employer fixed effects. }\end{array}$} \\
\hline
\end{tabular}

